\title{
CELLS INVOLVED IN THE IMMUNE RESPONSE
}

\author{
XII. The Differing Responses of Normal Rabbit Lymphoid Cells \\ to Phytohemagglutinin, Goat Anti-Rabbit Immunoglobulin \\ Antiserum and Allogeneic and Xenogeneic Lymphocytes* \\ BY FRITZ DAGUILLARD, $\ddagger$ M.D,. AND MAXWELL RICHTER, $\S$ M.D. \\ (From The Harry Webster Thorp Laboratories, Division of Immunochemistry and \\ Allergy, McGill University Clinic, Royal Victoria Hospital, \\ Montreal, Quebec, Canada)
}

(Received for publication 7 July 1969)

The past decade has been witness to a radical shift in the definition and classification of the lymphocytes. Until recently, the lymphocytes were considered to be a homogeneous population of cells in the animal body, albeit segregated into the different parenchymal lymphoid organs, with only the size of the mature cell to serve as a distinguishing criterion, the thymocyte being smaller than the lymphoid cells in the other lymphoid tissues. It has subsequently been demonstrated that, far from being even relatively homogeneous, the lymphocytes constitute an extremely heterogeneous population of cells, using the following nonimmunologic considerations as criteria: (a) The life span of the cell (short-lived versus long-lived lymphocytes) $(1,2) ;(b)$ The central or peripheral origin of the cell $(3,4) ;(c)$ The dependency of the cell on external lymphoid influence, i.e., thymic and bursal dependence $(5,6) ;(d)$ The differential migratory pathways of the lymphoid cells of the various lymphoid organs (7); (e) The physical fractionation of the cells on a gradient (8-10).

In a previous communication, we have demonstrated that the lymphocytes in the normal rabbit can be differentiated on the basis of their responses to phytohemagglutinin (PHA) ${ }^{1}(11)$ and antigens (12). We have now investigated further the question of the heterogeneity of the normal lymphoid cell population on the basis of the response to PHA, anti-immunoglobulin antiserum, and allogeneic and xenogeneic cell stimuli, and on their capacity to adsorb radio-

* This investigation was supported by a grant from the Medical Research Council, Canada. $\ddagger$ Submitted in partial fulfillment of the degree of Doctor of Philosophy, Department of Experimental Medicine, McGill University, Montreal. Present address, Hôpital du Saint Sacrement, Quebec, P.Q., Canada.

\$ Medical Research Associate, Medical Research Council, Canada.

${ }^{1}$ Abbreviations used in this paper: ALS, anti-lymphocyte serum; GARIG, goat anti-rabbitimmunoglobulin antiserum; Med-PS, Medium 199 containing penicillin (100 units/ml) and streptomycin $(100 \mu \mathrm{g} / \mathrm{ml})$; Med-PS-NRS, Medium 199 containing normal rabbit serum $(15 \%)$, penicillin (100 units $/ \mathrm{ml})$, and streptomycin $(100 \mu \mathrm{g} / \mathrm{ml}) ;$ PHA, phytohemmagglutinin; NGGG, normal goat gamma globulin. 
actively-labeled anti-immunoglobulin antiserum. The results presented below leave no doubt as to the functional heterogeneity of the lymphocytes in the normal rabbit.

\section{Materials and Methods}

Adult, New Zealand white rabbits, varying in age from 4-6 months, were used in this study. The phytohemagglutinin (PHA) used was phytohemagglutinin $\mathrm{M}$ obtained from Difco Laboratories, Detroit, Mich. The contents of a vial were dissolved in $5 \mathrm{ml}$ of sterile Medium 199 (Microbiological Associates, Inc., Bethesda, Md.,) and this solution, referred to as undiluted PHA, was diluted 5- and 10-fold in Medium 199. Normal goat gamma globulin (NGGG) was obtained from Pentex, Inc., Kankakee, Ill. The anti-immunoglobulin serum used was a goat anti-rabbit-immunoglobulin antiserum (GARIG), the preparation and characteristics of which have been previously described (13). The goats were each given 3 intramuscular injections of rabbit immunoglobulin $(100 \mathrm{mg})$ in complete Freund's adjuvant at 7-day intervals. The immunoglobulins were purified by filtration through a column of Sephadex G-200 and DEAE-cellulose. The goats were bled $2 \mathrm{wk}$ after the third injection of the antigen. The complement $(C)$ used was fresh whole guinea pig serum obtained by repeated cardiac puncture of normal, adult guinea pigs. The pooled serum was absorbed with rabbit red cells and kept frozen at $-20^{\circ} \mathrm{C}$ until used.

The rabbits were sacrificed by the intravenous administration of nembutal $(50 \mathrm{mg} / \mathrm{kg}$ body weight) and the various organs were removed in rapid order, the entire procedure taking no longer than several minutes. The organs removed were bone marrow (femur and tibia), popliteal lymph node, spleen, thymus, appendix, and sacculus rotundus. Where peripheral lymphocytes were to be tested as well, the rabbit was bled from the heart with a heparinized sterile syringe prior to sacrifice. The blood was diluted with $6 \%$ dextran in saline (mol wt 250,000) (Pharmacia Fine Chemicals, Inc. Uppsala, Sweden) in a ratio of 3:1 (blood:dextran) The mixture was introduced into sterile disposable plastic tubes (Falcon Plastics, Los Angeles, Calif.) which were placed in an incubator at $37^{\circ} \mathrm{C}$ and allowed to sediment at a $60^{\circ}$ angle for $45 \mathrm{~min}$. The leukocyte-rich plasma-dextran layer was then carefully decanted, diluted 10 -fold with Medium 199 and centrifuged at $1500 \mathrm{rpm}$ for $10 \mathrm{~min}$. The cells were resuspended in Medium 199 and washed once more before use ( $800 \mathrm{rpm}$ for $10 \mathrm{~min}$ ). The organs other than the bone marrow were cut into small fragments and teased through a sterile wire mesh ( 50 mesh) into Medium 199 by the application of slight pressure. The bone marrow cell suspensions were prepared by flushing the bone marrow with several portions of normal rabbit serum (NRS) (Microbiological Associates) into sterile plastic tubes. We have observed that the stability of the bone marrow cell suspension is enhanced if NRS is used in place of Medium 199 and heparin. The cell mass was gently shaken in the plastic tubes and centrifuged at $500 \mathrm{rpm}$ for $5 \mathrm{~min}$. The fatty upper layer was decanted and the cell button was suspended in Medium 199 containing homologous NRS (final concentration 15\%). The cell suspensions of the various organs were diluted in Medium 199 containing normal rabbit serum (15\%), penicillin (100 units $/ \mathrm{ml})$, and streptomycin $(100 \mu \mathrm{g} / \mathrm{ml})$ (Med-PS-NRS) to contain $10^{6}$ to $10^{7}$ cells per $\mathrm{ml}$. The various protocols carried out in this investigation are presented in Fig. 1.

I. Stimulation of Rabbit Lymphoid Cells in Vitro with $P H A$ or GARIG.-

The technique used for cell culture has been described previously (12) and is outlined in Fig. 2. The cells were suspended in Medium 199 containing penicillin (100 units/ml) and streptomycin $(100 \mu \mathrm{g} / \mathrm{ml})$ (Med-PS) to which was added either NRS or gamma globulin-free NRS. The latter was prepared by precipitating the gamma globulins at $50 \%$ saturation with ammonium sulfate. The supernatant, essentially free of gamma globulin by electrophoresis on cellulose acetate strips and immunoelectrophoresis, was dialyzed extensively against distilled water, then lyophilized and dissolved in Medium 199 to a concentration of $15 \%$. The pH 
was adjusted to 7 with sodium bicarbonate. $4 \mathrm{ml}$ portions of each of the cell suspensions $\left(10^{6}-10^{7}\right.$ cells $/ \mathrm{ml}$ ) were transferred to sterile disposable (Falcon) plastic tubes. $0.25 \mathrm{ml}$ of the PHA solution or 0.1 or $0.2 \mathrm{ml}$ of GARIG was added to each tube. Control tubes received 0.1 $\mathrm{ml}$ of normal goat serum or gamma globulin (Pentex). The tubes were sealed and incubated at $37^{\circ} \mathrm{C}$ for 3 days.

$16 \mathrm{hr}$ prior to termination of culture, $2 \mu \mathrm{c}$ tritiated thymidine (specific activity, 1 curie per mmole) were added to each tube. At the conclusion of culture, the tubes were centrifuged at $2000 \mathrm{rpm}$ for $15 \mathrm{~min}$, washed twice with $2 \mathrm{ml}$ of $5 \%$ trichloroacetic acid, digested overnight with $0.5 \mathrm{ml}$ Hyamine $10 \times$ (Packard Instrument Co., Inc., Downers Grove, Ill.) and transferred to counting vials to each of which was added $15 \mathrm{ml}$ scintillation solution (12). The radioactive content of the vials was determined in a model 4000 Packard scintillation counter.

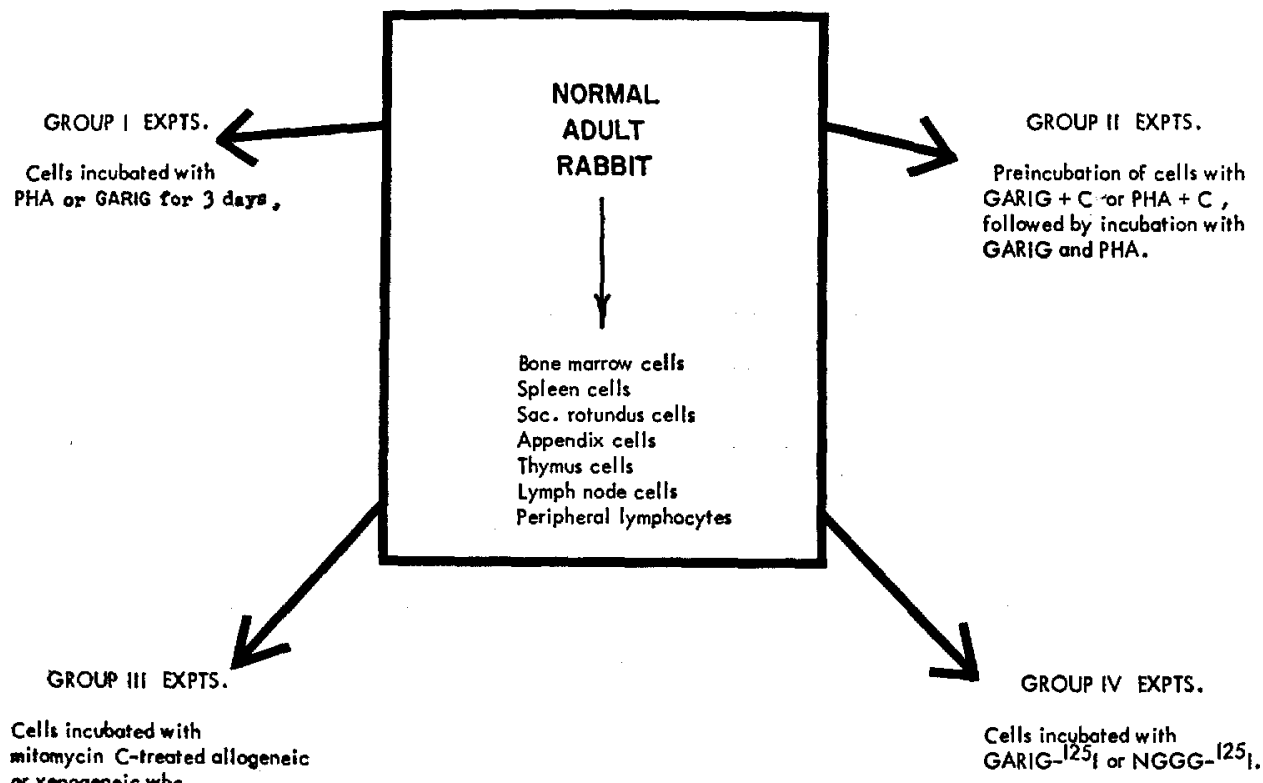
or xenogeneic wbe.

FIG. 1. Protocols for the demonstration of the functional heterogeneity of lymphoid cells in the different lymphoid organs in the normal rabbit.

The results are expressed as counts per minute per culture tube, counts per minute per $10^{6}$ cells, or as specific activity, which is defined as the ratio of the uptake of tritiated thymidine by the cells in the presence of the stimulating agent to that taken up in its absence.

II. The Effect of Preincubation of Rabbit Lymphoid Cells with GARIG and Complement or $P H A$ and Complement on the Subsequent Response to GARIG and PHA.-

Cells of six of the organs previously enumerated (appendix, bone marrow, lymph node, spleen, peripheral blood, sacculus rotundus) were prepared in suspensions containing 4-8 $\times$ $10^{6} \mathrm{lymphocytes} / \mathrm{ml}$. The thymus cells were prepared as a suspension of $20-40 \times 10^{6}$ cells/ $\mathrm{ml} .1 \mathrm{ml}$ portions of each cell suspension were dispensed into Falcon plastic tubes and sets of 6 tubes were each incubated for $1 \mathrm{hr}$ at $37^{\circ} \mathrm{C}$ with one of the following reagents: complement, 0.1 or $0.25 \mathrm{ml}$; PHA, $0.25 \mathrm{ml}$; GARIG, $0.2 \mathrm{ml}$; GARIG, $0.2 \mathrm{ml}$ plus complement, $0.25 \mathrm{ml}$; or PHA, $0.25 \mathrm{ml}$ plus complement, $0.25 \mathrm{ml}$. After incubation, all the cell suspensions were washed twice in Medium 199 and that of each tube was resuspended in $4 \mathrm{ml}$ of culture medium containing $15 \%$ gamma globulin-depleted NRS to give final cell concentrations of 5-10 $\times 10^{6}$ 
cells $/ \mathrm{ml}$ in the case of the thymus or $1-2 \times 10^{6}$ cells $/ \mathrm{ml}$ for all the other organs. Of each set of 6 tubes, two received PHA (diluted 10-fold, $0.25 \mathrm{ml}$ ), two received GARIG $(0.1 \mathrm{ml})$, and two were kept as control. All the tubes were cultured for 3 days and processed as described above under section I.

III. Stimulation of Rabbit Lymphoid Cells with Mitomycin C Inactivated Allogeneic and Xenogeneic Cells.-

Human and rabbit peripheral leukocytes were used as stimulating cells. Human cells were obtained by gravity sedimentation of heparinized blood at $37^{\circ} \mathrm{C}$ for $45-60 \mathrm{~min}$. As stated
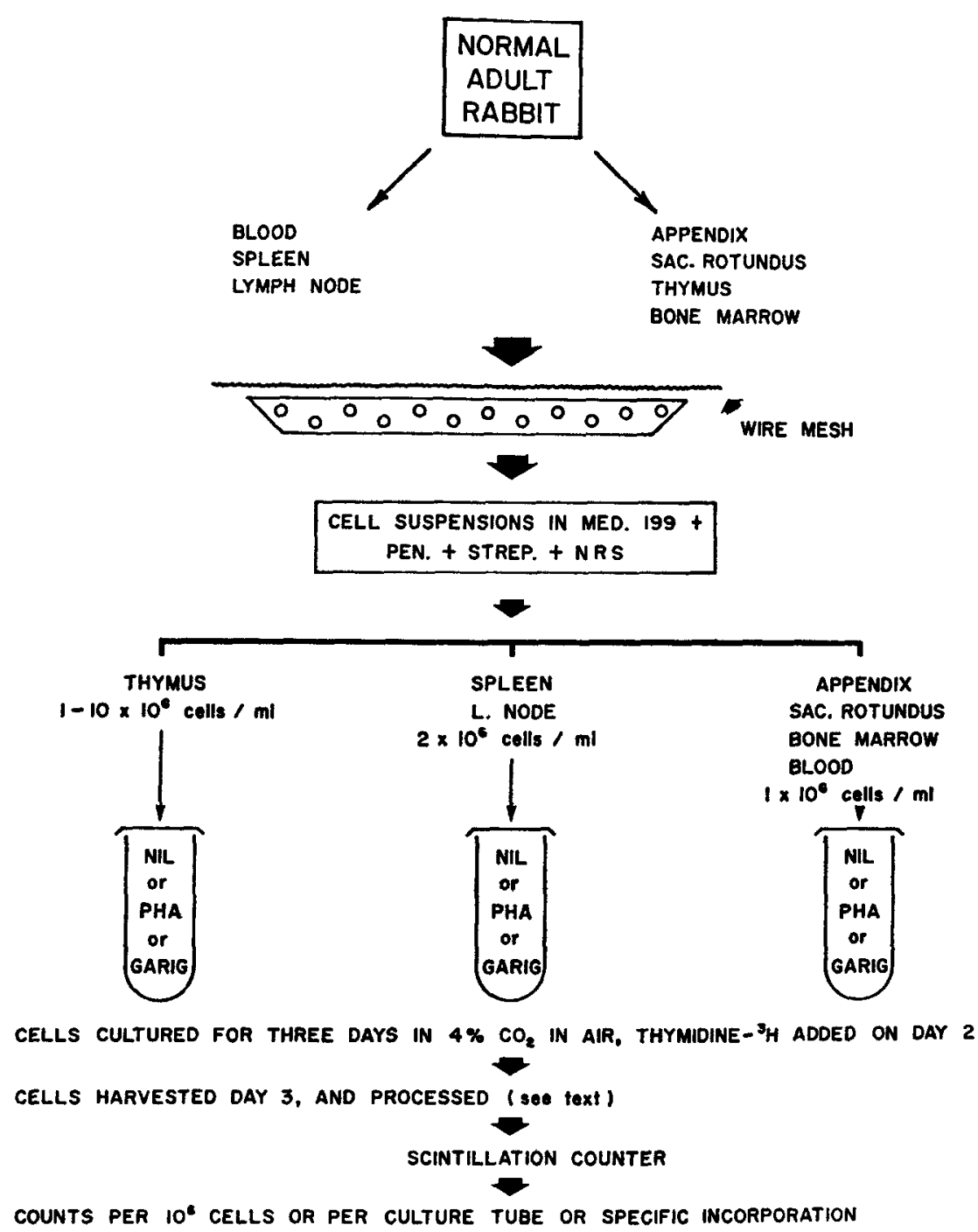

COUNTS PER $10^{\circ}$ CELLS OR PER CULTURE TUBE OR SPECIFIC INCORPORATION

FIG. 2. Procedure for the culture of rabbit lymphoid cells stimulated with PHA or GARIG in vitro. 
above, rabbit blood was mixed with dextran before sedimentation. The leukocytes recovered by centrifugation of the buffy coat were washed twice in Medium 199 and resuspended in Medium 199 containing $15 \%$ normal rabbit serum in a concentration of $2 \times 10^{6}$ cells per ml. The one-way stimulation test was carried out by the method of Bach and Voynow (14). The leukocytes were incubated with 25 gamma Mitomycin C (Nutritional Biochemicals Corp., Cleveland, Ohio) per $\mathrm{ml}$ of cell suspension for $20 \mathrm{~min}$ at $37^{\circ} \mathrm{C}$, followed by 3 washes to remove the drug. The cells of the lymphoid organs of the rabbits, referred to as the responding cells, were suspended in Med-PS-NRS in a cell concentration of $2 \times 10^{6}$ cells $/ \mathrm{ml}$ and tested for their ability to respond to the mitomycin $\mathrm{C}$ treated rabbit (allogeneic) and human (xenogeneic) leukocytes. The stimulating cells were mixed with an equal number of responding cells to give a final combined cell concentration of $2 \times 10^{6}$ cells $/ \mathrm{ml}$ in a total volume of $4 \mathrm{ml}$. Thymus cells were generally used in higher concentrations $\left(2-10 \times 10^{6}\right.$ cells $\left./ \mathrm{ml}\right)$ for reason discussed below. The mixed leukocyte cultures were maintained for 5 days at $37^{\circ} \mathrm{C}$. Tritiated thymidine $(2 \mu \mathrm{c})$ was added to each tube about $16 \mathrm{hr}$ prior to the termination of culture and the extent of radio-

\section{TABLE I}

Tritiated Thymidine Uptake of Normal Rabbit Spleen Lymphocytes Incubated With $P H A$ or GARIG for 3 or 5 Days in Cell Culture In Vitro

\begin{tabular}{lccc}
\hline & Day of addition & \multicolumn{2}{c}{ Tritiated thymidine uptake by cultures } \\
\cline { 3 - 4 } of stimulant & & Day 3 & Day 5 \\
\hline None & $0 \neq$ & 1,259 & 594 \\
NGGG per culture* & 1,360 & 670 \\
PHA & 0 & 14,623 & 723 \\
PHA & 0 & - & 4,819 \\
GARIG & 2 & 6,074 & 1,384 \\
\hline
\end{tabular}

* Counts per minute. Each value represents the mean of triplicate determinations.

$\ddagger$ Day 0 represents the beginning of incubation.

active incorporation by the responding cells was determined by the method described in section $\mathbf{I}$.

IV. The Uptake of GARIG-125I and NGG-125I by Normal Rabbit Lymphoid Cells.--

The gamma globulin fraction of GARIG was prepared by ammonium sulfate precipitation according to the method of Stelos (15), and it was further purified on a DEAE-cellulose column containing 1-2 $\mathrm{g}$ dry weight of the anion per $\mathrm{mg}$ of protein to be fractionated. The protein recovered after elution with phosphate-buffered saline ( $\mathrm{pH} 8,0.0175 \mathrm{M}$ ), had the immunoelectrophoretic characteristics of $\mathrm{IgG}$ and was labeled with ${ }^{125} \mathrm{I}$ at the rate of 1 atom of iodine per molecule of protein by the iodine monochloride method of McFarlane (16). NGGG was labeled in an identical fashion. These preparations are referred to as GARIG- ${ }^{125} \mathrm{I}$ and NGGG${ }^{125} \mathrm{I}$, respectively. $1 \mathrm{ml}$ portions of each of the lymphoid cell suspensions $\left(10^{6}\right.$ cells $\left./ \mathrm{ml}\right)$ prepared from the various lymphoid organs or of a suspension of erythrocytes $\left(10^{6}\right.$ cells $\left./ \mathrm{ml}\right)$ were incubated with equivalent amounts of either GARIG- ${ }^{125} \mathrm{I}$ orNGGG- ${ }^{125} \mathrm{I}$ for 2 or $24 \mathrm{hr}$ at $37^{\circ} \mathrm{C}$. The cell suspensions were then washed 5 times with $10 \mathrm{ml}$ of medium each time. The washed cells and the last washes were analyzed for their radioactive content using a Packard gamma counter. The results are presented as counts per minute per $10^{6}$ cells and as specific activity, which is defined as the ratio of uptake of radioactivity by the lymphoid cells to that taken up by the red cells. 


\section{RESULTS}

I. Response of Rabbit Lymphocytes to PHA and GARIG.-

As can be seen in Table I, the time for optimal and maximum stimulation of rabbit spleen cells by both PHA and GARIG was 3 days in our test system. Cells incubated with NGGG for 3 days did not incorporate more tritiated thymi-

TABLE II

Incorporation of Tritiated Thymidine by Normal Rabbit Spleen Cells Cultured In Vitro for 3 Days in Medium Containing Normal or Gamma Globulin Depleted Homologous Serum

\begin{tabular}{lcc}
\hline & \multicolumn{2}{c}{$\begin{array}{c}\text { Incorporation of tritiated thymidine by cells incubated } \\
\text { in medium enriched with }\end{array}$} \\
\cline { 2 - 3 } Stimulant used & Normal rabbit seru & $\begin{array}{c}\text { Gamma globulin depleted } \\
\text { rabbit serum }\end{array}$ \\
\hline & & \multicolumn{2}{c}{ cpm per culture" } \\
None & 927 & 1218 \\
PHA & 4257 & 4463 \\
GARIG & 2368 & 5959 \\
\hline
\end{tabular}

* Each value represents the mean of triplicate determinations.

TABLE III

The Effect of Varying the Incubation Time of Normal Rabbit Spleen Cells with PHA and GARIG on the Subsequent Incorporation of Tritiated Thymidine by the Cells Incubated in Culture for 3 Days

\begin{tabular}{lccc}
\hline Stimulant added & $\begin{array}{c}\text { Duration of incubation } \\
\text { with stimulant }\end{array}$ & $\begin{array}{c}\text { Duration of incubation in } \\
\text { absence of stimulant }\end{array}$ & $\begin{array}{c}\text { Incorporation of } \\
\text { tritiated thymidine } \\
\text { by the cells after } 3 \\
\text { days of culture }\end{array}$ \\
\hline None & Nil & 3.00 days & $\begin{array}{c}\text { cpm per culture* } \\
\text { PHA }\end{array}$ \\
PHA & $1 \mathrm{hr}$ & 3.00 days & 490 \\
PHA & $6 \mathrm{hr}$ & 2.75 days & 2725 \\
GARIG & 3 days & Nil & 3075 \\
GARIG & 1 hr & 3.00 days & 3150 \\
GARIG & 1 day & 2.00 days & 500 \\
GARIG & 2 days & 1.00 days & 550 \\
\hline
\end{tabular}

* Each value represents the mean of triplicate determinations.

dine than did control cultures. The stimulation with GARIG was greater when the cells were cultured in medium fortified with NRS depleted of gamma globulin, as compared to medium containing whole NRS (Table II). PHA and GARIG showed great differences with respect to the period of time necessary for incubation with the lymphocytes in order to get maximum stimulation. 
Only $1 \mathrm{hr}$ of incubation with PHA, followed by incubation for 3 days without PHA, was sufficient to permit optimal stimulation of the normal rabbit spleen cells (Table III). Similar results were obtained with the lymphoid cells of the other organs tested. Such was not the case with GARIG, however. Incubation of the lymphocytes with GARIG for 1, 6, or $24 \mathrm{hr}$ followed by incubation for 3, 2.75 , or 2 days without GARIG, respectively, resulted in no significant stimu-

TABLE IV

Proliferative Response of Normal Rabbit Lymphocytes to $P H A$ and GARIG

\begin{tabular}{|c|c|c|c|c|c|c|}
\hline \multirow{2}{*}{ Cells of organ tested } & \multirow{2}{*}{$\begin{array}{c}\text { Cell } \\
\text { conc/ml } \\
(4 \mathrm{ml})\end{array}$} & \multicolumn{3}{|c|}{ Stimulant used } & \multicolumn{2}{|c|}{$\begin{array}{l}\text { Mean specific } \\
\text { activityf }\end{array}$} \\
\hline & & Control & GARIG & PHA & GARIG & PHA \\
\hline & \multicolumn{6}{|c|}{ cpm per culture* } \\
\hline Thymus & $10 \times 10^{6}$ & 1,292 & 1,938 & 14,509 & 1.5 & 13.0 \\
\hline Bone marrow & $1 \times 10^{6}$ & 31,250 & 83,457 & 85,443 & 2.4 & 2.2 \\
\hline Spleen & $2 \times 10^{6}$ & 2,460 & 13,755 & 11,105 & 6.2 & 8.3 \\
\hline Lymph nodes & $2 \times 10^{6}$ & 693 & 6,838 & 5,981 & 9.5 & 7.3 \\
\hline Sacculus rotundus & $1 \times 10^{6}$ & 205 & 4,612 & 13,192 & 11.0 & 44.0 \\
\hline Peripheral lymphocytes & $1 \times 10^{6}$ & 1,204 & 16,513 & 11,412 & 22.0 & 7.0 \\
\hline Appendix & $1 \times 10^{6}$ & 94 & 3,019 & 615 & 30.0 & 5.6 \\
\hline
\end{tabular}

* Based on a single experiment. Mean value of triplicate determinations.

¥ Ratio of thymidine uptake by stimulated culture to that taken up in control culture. Based on five different experiments.

TABLE V

The In Vitro Response to $P H A$ and GARIG of Normal Rabbit Thymocytes Incubated at Different Cell Concentrations

\begin{tabular}{|c|c|c|c|}
\hline \multirow{2}{*}{ Cell conc/ml } & \multicolumn{3}{|c|}{ Uptake of tritiated thymidine by the thymus cells incubated in the presence of } \\
\hline & No stimulant added & PHA & GARIG \\
\hline & \multicolumn{3}{|c|}{ cpm per culture* } \\
\hline $1 \times 10^{6}$ & 323 & 188 & 267 \\
\hline $1 \times 10^{6}$ & 125 & 460 & 230 \\
\hline $1 \times 10^{6}$ & 752 & 1,463 & 765 \\
\hline $5 \times 10^{6}$ & 708 & 5,030 & 1,102 \\
\hline $5 \times 10^{6}$ & 530 & 6,482 & 531 \\
\hline $10 \times 10^{8}$ & 466 & 3,733 & 1,006 \\
\hline $10 \times 10^{6}$ & 530 & 15,251 & 364 \\
\hline $10 \times 10^{6}$ & 311 & 2,198 & 303 \\
\hline $10 \times 10^{6}$ & 1,292 & 14,509 & 1,938 \\
\hline $10 \times 10^{6}$ & 607 & 5,858 & 1,229 \\
\hline
\end{tabular}

* Each value represents the mean of triplicate determinations. 
lation. Optimal stimulation with GARIG was observed only if the cells were incubated with this stimulant for the entire culture period (Table III).

All the cells of the various lymphoid organs tested, except for the thymus, gave an optimal response to PHA when incubated in a concentration of $1-2 \times 10^{6}$ cells $/ \mathrm{ml}$ (Table IV). The thymus cells reacted optimally to PHA at a cell concentration of $10^{7}$ per ml (Table V). Although the thymus lymphocytes at times responded to PHA when cultured at a lower cell concentration (1-2 $\times 10^{6}$ cells $\left./ \mathrm{ml}\right)$, their response to PHA could be markedly improved by increasing the cell concentration to $5-10 \times 10^{6} \mathrm{cells} / \mathrm{ml}$ (Table V).

The lymphoid cells of all the organs tested responded to both PHA and GARIG except the thymus cells which did not respond to GARIG or responded very inconsistently (Table IV and V). The response of the different lymphoid

TABLE VI

The Incorporation of Tritiated Thymidine by Normal Rabbit Spleen Cells Stimulated with PHA or GARIG after Preincubation of the Cells for $1 \mathrm{Hr}$ with GARIG and Complement (C), $P H A$ and $C, C, P H A$ or $G A R I G$

\begin{tabular}{lccc}
\hline \multirow{2}{*}{$\begin{array}{c}\text { Cells preincubated for } \\
\text { 1 hr with }\end{array}$} & \multicolumn{3}{c}{$\begin{array}{c}\text { Incorporation of tritiated thymidine by the preincubated cells after } \\
\text { incubation for } 3 \text { more days in the presence of }\end{array}$} \\
\cline { 2 - 4 } & Nil & PHA & GARIG \\
\hline Nil & 336 & 3693 per cullure* & 1458 \\
C & 387 & 2941 & 1002 \\
PHA & 2729 & 2892 & 5285 \\
PHA + C & 2701 & 2403 & 4118 \\
GARIG & 458 & 4569 & 1245 \\
GARIG + C & 334 & 4141 & 302 \\
\hline
\end{tabular}

* Each value represents the mean of triplicate determinations.

cell suspensions varied markedly, however, being only marginal for the bone marrow cells, which displayed a specific activity of no more than 2 to 3 (Table IV).

II. The Effect of Preincubation of Rabbit Lymphoid Cells with GARIG and Complement or $P B A$ and Complement on the Subsequent Response to GARIG and $P H A$.-

As can be seen in Table VI, pretreatment of the spleen cells with PHA for 1 $\mathrm{hr}$ followed by culture for 3 days in the absence of PHA still resulted in almost maximum blastogenesis as compared to cultures incubated in the presence of PHA for the entire 3 day period. Interestingly enough, the addition of GARIG to the cell suspension, which had been preincubated with PHA or PHA and C for only $1 \mathrm{hr}$, induced a further increase in the blastogenic response of these cells, as compared to cells incubated with either GARIG or PHA alone, indicating an additive effect. This effect of PHA and GARIG could be demon- 
strated for the cells of all the lymphoid organs investigated, except for the thymus (Table VII). Preincubation of the cells with PHA and C did not alter the response of the cells as compared to cells pretreated with PHA only. Cells preincubated with C or GARIG for $1 \mathrm{hr}$ subsequently behaved in the same manner as control cells (Table VI). On the other hand, pretreatment of the cells for $1 \mathrm{hr}$ with GARIG and $\mathrm{C}$ resulted in complete suppression of the ability of the cells to subsequently respond to GARIG. However, the response to PHA

TABLE VII

Proliferative Response of Normal Rabbit Lymphoid Cells to $P H A$ and GARIG after Pretreatment for $1 \mathrm{Er}$ with GARIG and Complement or PHA and Complement (C)

\begin{tabular}{|c|c|c|c|c|c|c|c|}
\hline \multirow{2}{*}{$\begin{array}{l}\text { Cells of organ tested } \\
(4 \mathrm{ml})\end{array}$} & \multirow{2}{*}{$\begin{array}{c}\text { Stimulant } \\
\text { added }\end{array}$} & \multicolumn{6}{|c|}{ Uptake of tritiated thymidine by the cells pretreated with } \\
\hline & & Nil & $\underset{\mathrm{C}}{\mathrm{PHA}}+$ & $\underset{\mathbf{C}}{\operatorname{GARIG}}+$ & Nil & $\underset{+C}{\text { PHA }}$ & $\underset{+C}{\text { GARIG }}$ \\
\hline & & \multicolumn{3}{|c|}{ cptm per cullure* } & \multicolumn{3}{|c|}{ mean specific actioity $\ddagger$} \\
\hline \multirow{3}{*}{$\begin{array}{l}\text { Appendix } \\
1 \times 10^{6} / \mathrm{ml}\end{array}$} & None & 131 & 943 & 153 & & 8.0 & 1.2 \\
\hline & PHA & 1,256 & 1,275 & 1,728 & 8.7 & 8.1 & 8.0 \\
\hline & GARIG & 818 & 1,627 & 201 & 7.8 & 12.0 & 1.1 \\
\hline \multirow{3}{*}{$\begin{array}{l}\text { Bone marrow } \\
1 \times 10^{6} / \mathrm{ml}\end{array}$} & None & 7,826 & 12,754 & 7,681 & & 2.0 & 0.9 \\
\hline & PHA & 23,764 & 15,767 & 17,731 & 2.4 & 2.2 & 2.2 \\
\hline & GARIG & 16,446 & 23,789 & 7,416 & 2.2 & 2.4 & 0.9 \\
\hline \multirow{3}{*}{$\begin{array}{l}\text { Lymph node } \\
2 \times 10^{6} / \mathrm{ml}\end{array}$} & None & 323 & 2,506 & 729 & & 10.0 & 1.2 \\
\hline & PHA & 4,609 & 3,413 & 6,771 & 12.0 & 12.4 & 10.0 \\
\hline & GARIG & 1,553 & 5,220 & 751 & 8.0 & 16.0 & 1.2 \\
\hline \multirow{3}{*}{$\begin{array}{l}\text { Periperhal } \\
\text { lymphocytes } \\
1 \times 10^{6} / \mathrm{ml}\end{array}$} & None & 770 & 2,952 & 428 & & 6.0 & 1.1 \\
\hline & PHA & 3,500 & 3,433 & 2,508 & 6.0 & 8.1 & 6.3 \\
\hline & GARIG & 2,590 & 5,843 & 504 & 6.2 & 11.7 & 1.2 \\
\hline \multirow{3}{*}{$\begin{array}{l}\text { Spleen } \\
2 \times 10^{6} / \mathrm{ml}\end{array}$} & None & 305 & 4,066 & 444 & & 10.0 & 1.1 \\
\hline & PHA & 5,593 & 4,858 & 6,053 & 12.0 & 12.5 & 15.0 \\
\hline & GARIG & 6,502 & 9,099 & 569 & 9.1 & 19.0 & 1.1 \\
\hline \multirow{3}{*}{$\begin{array}{l}\text { Sacculus rotundus } \\
1 \times 10^{6} / \mathrm{ml}\end{array}$} & None & 238 & 2,686 & 211 & & 17.0 & 0.9 \\
\hline & PHA & 4,576 & 3,761 & 3,272 & 20.0 & 17.7 & 15.0 \\
\hline & GARIG & 1,607 & 4,022 & 312 & 7.1 & 22.0 & 1.8 \\
\hline \multirow{3}{*}{$\begin{array}{l}\text { Thymus } \\
5 \times 10^{6} / \mathrm{ml}\end{array}$} & None & 170 & 1,118 & 215 & & 10.0 & 1.0 \\
\hline & PHA & 1,713 & 1,384 & 1,757 & 10.0 & 8.7 & 11.0 \\
\hline & GARIG & 237 & 1,048 & 260 & 1.2 & 9.0 & 1.2 \\
\hline
\end{tabular}

* Each value represents the mean of triplicate determinations. Values are representative of a single experiment.

$\ddagger$ Ratio of thymidine uptake by stimulated culture to that taken up by control culture. Values based on five different experiments. 
was, if anything, enhanced (Table VI). This effect of preincubation of lymphoid cells with GARIG and C was consistently found for cells of all the lymphoid organs evaluated (Table VII).

III. Response of Rabbit Lymphocytes to Mitomycin-C-Treated Allogeneic and Xenogeneic Cells. -

The response of rabbit lymphoid cells stimulated with mitomycin C-treated

TABLE VIII

Response of Rabbit Lymphocytes to Xenogeneic and Allogeneic Mitomycin C-Treated-Leukocytes

\begin{tabular}{|c|c|c|c|c|c|c|}
\hline \multirow{2}{*}{ Cells of organ tested } & \multirow{2}{*}{$\begin{array}{c}\text { Cell conc/ml } \\
(4 \mathrm{ml})\end{array}$} & \multicolumn{3}{|c|}{ Stimulant used } & \multicolumn{2}{|c|}{ Mean specific activity" } \\
\hline & & Control & $\mathbf{H}_{\mathbf{m}} \ddagger$ & $\mathbf{R}_{\mathbf{m}} \mathbf{\delta}$ & $\mathrm{H}_{\mathbf{m}}$ & $\mathbf{R}_{\mathbf{m}}$ \\
\hline & \multicolumn{6}{|c|}{ cpm per culturell } \\
\hline Appendix & $1 \times 10^{6}$ & 104 & 3232 & 642 & 22.0 & 4.5 \\
\hline Bone marrow & $1 \times 10^{6}$ & 3100 & 7286 & 1638 & 3.0 & 1.2 \\
\hline Sacculus rotundus & $1 \times 10^{6}$ & 160 & 6171 & 1817 & 11.0 & 6.0 \\
\hline Peripheral lymphocytes & $1 \times 10^{6}$ & 212 & 1015 & 1700 & 4.3 & 3.9 \\
\hline Lymph nodes & $1 \times 10^{6}$ & 82 & 1426 & 7145 & 18.0 & 40.0 \\
\hline Spleen & $1 \times 10^{6}$ & 773 & 2178 & 1647 & 5.7 & 1.6 \\
\hline Thymus & $1 \times 10^{6}$ & 20 & 271 & 51 & 10.8 & 2.6 \\
\hline Thymus & $5 \times 10^{6}$ & 33 & 917 & 57 & 26.6 & 2.5 \\
\hline
\end{tabular}

* Ratio of thymidine uptake by stimulated culture to that taken up in control culture. Based on five different experiments.

$\ddagger \mathrm{H}_{\mathrm{m}}$, Mitomycin-treated human peripheral leukocytes.

$\$ R_{m}$, Mitomycin-treated rabbit peripheral leukocytes.

II Based on a single experiment. Mean value of triplicate determinations.

TABLE IX

Uptake of Radioactivity by Normal Rabbit Red Blood Cells and Lymphoid Cells after Incubation for 2 He with NGGG-125I

\begin{tabular}{lcc}
\hline Cells of organ incubated & $\begin{array}{c}\text { Uptake of radioactivity by } \\
\text { the incubated cells }\end{array}$ & Specific activity* \\
\hline & cpm per 106 cells & \\
Appendix & 2852 & 1.1 \\
Bone marrow & 5371 & 2.1 \\
Lymph node & 2706 & 1.1 \\
Peripheral lymphocytes & 6023 & 2.4 \\
Spleen & 6550 & 2.7 \\
Sacculus rotundus & 2635 & 1.1 \\
Thymus & 2271 & 0.9 \\
& & - \\
Red blood cells & 2520 & - \\
\hline
\end{tabular}

* The specific activity is defined as the ratio of the uptake of NGGG- ${ }^{125} \mathrm{I}$ by the lymphoid cell suspension to that taken up by the red blood cells.

$\ddagger$ Each value represents the mean of triplicate determinations. 
allogeneic and xenogeneic cells was optimum at day 5, although at times a slightly greater response in terms of absolute counts could be obtained at day 7 . All cultures were therefore terminated on day 5 .

All the rabbit lymphoid cells responded to the xenogeneic stimulus (human peripheral lymphocytes inactivated with mitomycin C) (Table VIII). However, the response was generally diminished when allogeneic cells (mitomycin C-treated rabbit peripheral leukocytes or spleen cells) were used as stimulant. The rabbit bone marrow and spleen cells responded only slightly (Table VIII). The response of thymus lymphocytes was comparable with that of the other lymphoid cells.

TABLE X

Uptake of Radioactivity by Normal Rabbit Red Blood Cells and Lymphoid Cells after Incubation for $2 \mathrm{Br}$ with GARIG-125I

\begin{tabular}{lcc}
\hline Cells of organ incubated & $\begin{array}{c}\text { Uptake of radioactivity by } \\
\text { the incubated cells }\end{array}$ & Specific activity* \\
\hline cpm per $10^{\circ}$ cellst & \\
Appendix & 12,446 & 4.9 \\
Bone marrow & 13,350 & 5.3 \\
Lymph node & 18,710 & 7.3 \\
Peripheral lymphocytes & 14,500 & 5.9 \\
Spleen & 35,053 & 13.7 \\
Sacculus rotundus & 10,844 & 4.2 \\
Thymus & 3,662 & 1.4 \\
Red blood cells & 2,550 & -
\end{tabular}

* The specific activity is defined as the ratio of the uptake of GARIG- ${ }^{125}$ I by the lymphoid cell suspension to that taken up by the red blood cells.

$\ddagger$ Each value represents the mean of triplicate determinations.

IV. Uptake of GARIG-125I and NGGG-125I by Normal Rabbit Lymphoid Cells.-

As can be seen in Table IX, the uptake of radioactivity by the different lymphoid cell populations incubated with equivalent amounts of NGGG-125I was about the same for all the organs studied and was not much greater than that taken up by the erythrocytes. On the other hand, the uptake of GARIG${ }^{125} \mathrm{I}$ by the lymphoid cells was much greater, with the sole exception of the thymus cells which adsorbed a lesser amount of radioactivity equal to that taken up by the rabbit erythrocytes (Table X).

The amount of radioactivity taken up by the cell suspensions incubated for $2 \mathrm{hr}$ with the labeled protein solutions was the same as that taken up after incubation of the cells for $24 \mathrm{hr}$. 


\section{DISCUSSION}

The results presented in this investigation lend strong support to the thesis that lymphoid cells intrinsic to the anatomically-segregated lymphoid organs vary greatly in their immunological functions, although they are similar, if not identical, in their gross morphological characteristics. Four criteria were utilized to differentiate the lymphoid cells, on a functional basis, in the normal rabbit. These are: $(a)$ the response to stimulation with phytohemagglutinin (PHA) in vitro; $(b)$ the response to stimulation with goat antiserum directed to rabbit immunoglobulins (GARIG); (c) the response to stimulation with allogeneic and xenogeneic cells; and $(d)$ the uptake of GARIG-25I by the different cell suspensions.

The initial series of experiments were carried out in order to establish the optimal conditions for the stimulation of the lymphoid cells by PHA or GARIG in vitro. It was observed that the optimal period of incubation was 3 days with respect to both stimulants (Table I) and that the response to GARIG was facilitated if the cells were cultured in medium fortified with gamma globulindepleted NRS rather than whole NRS (Table II). It has been demonstrated (17, 18) that normal lymphocytes can be stimulated by antigen-antibody complexes. to undergo blastogenesis and mitosis. The incubation of the cells in agammaglobulinemic serum obviates the stimulation of the normal lymphocytes by antibody-antigen complexes which would normally be formed by the interaction of normal rabbit gamma globulin in the medium with antibody directed to it in GARIG. Therefore, in all the subsequent experiments, the cells were incubated in Medium 199 containing 20\% gamma globulin-depleted NRS for a period of 3 days. Furthermore, it was found that incubation of the cells with PHA for only $1 \mathrm{hr}$, followed by incubation for 3 days in the absence of PHA, permitted for almost maximum stimulation of the cells, a finding made previously with human cells (19). On the other hand, preincubation of the cells with GARIG for only $1 \mathrm{hr}$ or 1 day followed by incubation of the cells for 3 or 2 days, respectively, in the absence of GARIG, did not result in a response greater than that obtained with the control cultures. In order to obtain a maximum response with GARIG, the cells had to be incubated with the stimulant for the entire duration of culture (Table III). The cell concentration varied from 1 to 2 million $/ \mathrm{ml}$, a cell concentration which has been found to permit blastogenesis (unpublished results).

The main findings can be presented as follows:

1. The lymphoid cells of all the lymphoid organs tested responded to PHA and GARIG, to varying degrees, except for the thymus cells which failed to respond to GARIG, even when tested in cell concentrations varying from 1 to 10 million $/ \mathrm{ml}$ of culture fluid. It is interesting to note that PHA at times failed to stimulate the thymic cells when the latter were incubated in a cell concentration of only 1 million cells/ml; however, the response to PHA by these cells 
incubated in a higher cell concentration was marked and in the range of the responses observed with the cells of the other lymphoid organs. Results of a similar nature, with regard to the relationship of thymic cell concentration and the response to PHA, have been observed previously by Knight et al. (20) and Claman and Brunstetter (21).

2. An additive effect was observed when GARIG was added to lymphoid cells which had been preincubated with PHA for $1 \mathrm{hr}$. The latter incubation was shown to be sufficient in most instances to result in optimal stimulation of the cells. The subsequent addition of GARIG to the cells for the duration of culture induced a proliferative effect significantly greater than that induced by either PHA or GARIG alone.

3. Preincubation of the cells with GARIG for $1 \mathrm{hr}$ did not inhibit the subsequent blastogenic effect of GARIG or PHA on the cells.

4. Preincubation of the lymphocytes with GARIG and complement selectively impaired the capacity of the cells to respond to GARIG but left intact their proliferative responsiveness to stimulation with PHA. On the other hand, preincubation of the cells with PHA and complement or complement alone did not affect the capacity of the cells to respond to stimulation with either PHA or GARIG. These findings suggest that incubation of the cells with GARIG and complement results in immune lysis of a select population of cells, those capable of reacting with the antirabbit immunoglobulin antibodies of GARIG. This complete suppression of responsiveness to GARIG was evident, although only $8-10 \%$ of the cells had been killed by the treatment with GARIG and complement, utilizing the dye exclusion test.

Since normal goat serum or gamma globulin does not exhibit blastogenic activity, the stimulus provided by GARIG can only be attributed to its property as an antiserum directed to rabbit immunoglobulins. It may therefore be presumed that the blastogenic response to GARIG is dependent on the reaction of antibodies in the antiserum with immunoglobulin receptor sites on the surface of the normal rabbit lymphoid cell. Various investigations have, in fact, disclosed the presence of such receptors on the surface of the immune lymphoid cell. Merler and Janeway (22) eluted immunoglobulin-like proteins from immune human tonsillar lymphocytes which possessed antibody-like activity toward the antigen to which the donor had been originally immunized. Paul et al. (23) found that the ability of an antigen to stimulate immune guinea pig lymphoid cells to undergo specific blastogenesis in vitro is directly related to its ability to bind to the lymphoid cells, thus implying that interaction between the antigen and a specific site (immunoglobulin?) on the immune lymphocyte surface is a prerequisite for the ensuing blastogenic response. McConnell et al. (24) and Mitchison (25) have both presented evidence favoring the immunoglobulin nature of the recognition site. McConnell et al. (24) observed that rosette formation by immune mouse lymph node cells in the presence of the 
specific antigen could be inhibited by prior treatment of these cells with antiserum directed to the heavy chains of mouse immunoglobulins, suggesting that immunoglobulins possessing antibody activity reside on the lymphocyte surface. Similarly, Mitchison (25) showed that antibody to a mouse immunoglobulin myeloma protein or to the Fab fragment of the norma mouse gamma globulin could inhibit the synthesis of specific antibody by immune cells exposed to the specific immunizing antigen in vitro. The results of these two latter studies suggest that the anti-immunoglobulin antibody and the specific antigen react with the same site or receptor on the lymphocyte which in all probability is an immunoglobulin. Singhal and Richter (12) and Singhal and Wigzell (26) have demonstrated that normal rabbit bone marrow lymphocytes are capable of reacting with blastogenesis and mitosis upon incubation with a variety of antigens in vitro. These lymphocytes must be considered to be virgin cells in that they had not previously been exposed to these antigens. Since normal rabbit bone marrow contains antigen-reactive cells only and no antibody-forming cells (27), it must be assumed that the antigen-reactive lymphoid cell possesses specific recognition sites as well, capable of interacting with the antigen.

The findings of Sell and Gell lend further support for the existence of an immunoglobulin recognition site on the normal rabbit lymphocyte. They demonstrated that homologous rabbit anti-allotype serum $(28,29)$ and heterologous anti-immunoglobulin antiserum (29) could stimulate normal rabbit lymphocytes to undergo blastogenesis and mitosis. The observation by Sell (30) that the univalent Fab fragment of the anti-immunoglobulin molecule could stimulate rabbit lymphocytes to transform indicates that only interaction of sites with a complimentary configuration is required to trigger this in vitro cell response. It has since been osbserved that heterologous anti-immunoglobulin antisera can induce blastogenesis of lymphocytes of a number of other animal species-guinea pigs (31), chickens (32), mice (33), and man (34-36). It has also been demonstrated that antilymphocyte serum (ALS) can induce blastogenesis of human (37-40) rabbit (41), and guinea pig (31) lymphocytes. Since the blastogenic activity of the antiimmunoglobulin antiserum can be suppressed after absorption of the antiserum with IgG (42) whereas the blastogenic activity of the ALS is not diminished after absorption with serum proteins (31) but can be depressed after absorption with lymph node cells (31), it may be concluded that the site on the surface of the lymphocyte to which the blastogenic factor in the ALS is directed is not an immunoglobulin related antigenically to the circulating immunoglobulins but is rather a membrane component. Recent studies suggest that PHA may interact with the same site(s) on the lymphocyte to which ALS is directed $(43,44)$. Preincubation of lymphoid cells with a subthreshold (nonmitogenic) dose of ALS could block stimulation 
of these cells by PHA $(43,44)$. The cells were not inactivated by the preincubation, since addition of a threshold dose of ALS could successfully stimulate the cells (44). We were unable to demonstrate a similar inhibitory effect by preincubation of the cells with GARIG. It is probable, therefore, that ALS and PHA interact with sites which are identical but different from the immunoglobulin-like receptors to which GARIG (normal lymphocytes) and antigens (precommitted and immune lymphocytes) are directed.

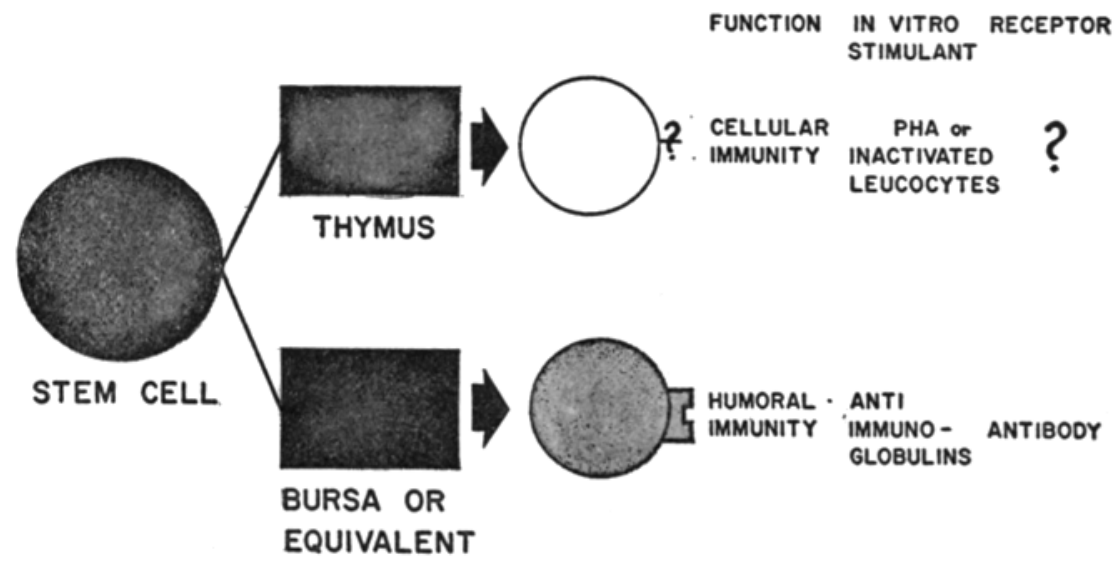

Fig. 3. The existence of a single or two populations of lymphocytes reactive toward PHA and GARIG. A diagramatic representation.

In a previous study from this laboratory (36), it was demonstrated that peripheral lymphocytes obtained from patients with agammaglobulinemia could be stimulated to undergo blastogenesis upon stimulation with PHA but not with anti-human immunoglobulin antiserum whereas peripheral lymphocytes of normal individuals could respond to stimulation by both these agents. This dissociation of responsiveness of human lymphocytes to PHA and anti-immunoglobulin serum in the cases of agammaglobulinemia and the findings with rabbit cells described above imply either that: $(a)$ there normally exist two populations of lymphocytes, one capable of responding to PHA and the other to anti-immunoglobulin antiserum, with the latter population of cells absent in the case of agammaglobulinemia (Fig. 3); or (b) that the capacity to respond to these two mitogenic agents is normally inherent in the same lymphocyte, but that in the case of a particular disease, such as agammaglobulinemia, the ability of the cell to respond to anti-immunoglobulin antiserum is lost. The findings presented in this investigation lend strong support to the former interpretation, since the response of the population of normal rabbit lymphoid cells to PHA was not diminished if the cells capable of responding to anti-immuno- 
globulin antiserum (GARIG) were initially inactivated by pretreatment of the cells with GARIG and guinea pig complement. These findings facilitate an understanding of the mode of action of PHA and anti-immunoglobulin antisera. Unlike PHA, which appears to stimulate the majority of the lymphocytes (45), anti-immunoglobulin antiserum would stimulate only those cells carrying specific sites, i.e., immunoglobulins, capable of interacting with the antiimmunoglobulin antibodies.

A point that requires further clarification is the failure of the normal rabbit thymus cells to respond to GARIG under conditions where the response to PHA is optimal. This finding suggests that thymocytes lack the specific immunoglobulin receptor(s) possessed by lymphoid cells of the other lymphoid organs. The low uptake of radioactively-labeled GARIG by the thymocytes, compared to the uptake by the other lymphoid cells, provides further support in favor of the absence of immunoglobulins on the thymocyte surface.

The failure of normal rabbit ${ }^{2}$ or mouse (46-48) thymus cells to confer the capacity to form antibodies upon transfer to irradiated recipient animals indicates that the thymus is not immunocompetent at the humoral level. On the other hand, thymocytes are capable of responding to stimulation by xenogeneic mitomycin-inactivated lymphocytes (the one-way stimulation test). In fact, the thymocytes responded as well, and at times better, than cells of the other lymphoid organs to the xenogeneic stimulus. Previous studies have shown that lymphoid cells of various organs of a number of animal species could respond with blastogenesis and DNA synthesis when stimulated in vitro with allogeneic (49-52) and xenogeneic (53) cells. However, in contrast to the easily demonstrable response of human lymphoid cells in mixed leukocyte cultures (50), rabbit lymphocytes are not as easily stimulated by homologous cells (54), a finding confirmed in our present experiments. In all cases, the stimulus provided by the xenogeneic cells was consistently found to be superior, even with respect to lymphoid cells which hardly responded in the presence of the allogeneic stimulus. The response of the lymphocytes in the mixed cell culture has definite immunologic characteristics. It cannot be induced by incubation of lymphocytes from identical monozygotic twins $(50,55)$ or syngeneic animals (56), nor by the incubation of lymphocytes from genetically dissimilar donors when one of the donors had been made tolerant to the cells of the other donor (57). Furthermore, in mixed leukocyte cultures consisting of leukocytes of parental and $F_{1}$ hybrid origin, all the dividing cells are of parental origin (57). The fact that rabbit thymus cells can react in the one-way stimulation test and can mediate the graft-versus-host reaction (58-62) indicates that thymocytes are capable of specific cellular immune manifestations.

${ }^{2}$ Abdou N. Y., and M. Richter. Unpublished results. 
On the assumption, as is generally accepted, that the mixed leukocyte response is representative of cellular immunity, the findings would support the currently accepted view that the cells mediating cellular immunity are thymic or thymus-derived and that their response to PHA is indicative of this immunologic function. It has been reported that the response of lymphocytes of neonatally thymectomized mice (63), rats (64), and chickens (65) to stimulation with PHA or mitomycin C-treated allogeneic cells is markedly reduced. Furthermore, it has been demonstrated that lymphocytes obtained from thymectomized rats are incapable of responding to stimulation with allogeneic lymphocytes in the mixed leukocyte system (57). On the other hand, spleen cells of hypogammaglobulinemic bursectomized chickens failed to respond to antiimmunoglobulin antiserum (42), although the response to PHA was normal $(42,64,65)$. Since immunocompetent cells capable of mediating humoral immunity are considered to be bursal-derived or -dependent, whereas cells which mediate cellular immunity are considered to be thymic-derived or -dependent, it would appear that responsiveness to PHA and/or allogeneic and xenogeneic cell stimuli may indeed provide a means of identifying those cells capable of mediating thymus-dependent cellular immunity. The presence of immunoglobulin sites on the surface of the cell, permitting it to respond to stimulation with GARIG, may therefore serve as a means of detecting and identifying cells capable of mediating humoral immunity.

These experiments present further evidence in favor of the division of the immune system into separate humoral and cellular branches. The recognition of the antigen by cells mediating the humoral immune response (antigenreactive and/or antibody-forming cells) would appear to require an immunoglobulin receptor site on the surface, capable of interacting with the antigen. Such a receptor appears not to exist on cells capable of mediating specific cellular immunity. The mechanism whereby these latter cells recognize antigen and interact with it remains to be determined.

\section{SUMMCARY}

Cells of the different lymphoid organs in the normal adult rabbit were investigated for their capacity to respond in vitro to a number of stimuli, such as phytohemagglutinin (PHA), anti-rabbit immunoglobulin antiserum (GARIG) and allogeneic and xenogeneic lymphoid cells, and for their capacity to adsorb radioactively-labeled anti-immunoglobulin antiserum. The bone marrow cells responded minimally to PHA, GARIG, and the allogeneic and xenogeneic stimuli. The thymus cells were unable to respond to stimulation with GARIG although they responded to the other stimuli. The cells of the other lymphoid organs tested responded to all the mitogenic agents, to varying degrees. 
On the basis of the results presented and the findings of other investigators, it is concluded that:

1. The response of the cells to GARIG indicates a potential capacity to mediate humoral immunity and requires the presence of immunoglobulin or immunoglobulin-like recognition sites on the cell surface.

2. The response of the cells to PHA and allogeneic and xenogeneic cells indicates a potential capacity to mediate cellular immunity and does not necessitate the presence of immunoglobulin-recognition sites on the cell surface.

3. The thymus in the normal adult rabbit consists of cells capable of mediating cellular immunity only.

4. The other lymphoid organs appear to possess cells capable of mediating humoral and cellular immunity.

\section{BIBLIOGRAPHY}

1. Weber, W. T., and P. C. Nowell. 1965. Studies on long-lived small lymphocytes in the rhesus monkey and some other mammals. RES J. Reticuloendothel. Soc. 2: 326.

2. Everett, N. B., and R. W. Tyler. 1967. Lymphopoiesis in the thymus and other tissues: Functional implications. Int. Rev. Cytol. 22:205.

3. Cooper, M. D., A. E. Gabrielsen, and R. A. Good. 1967. Role of the thymus and other central lymphoid tissues in immunological disease. Annu. Rev. Med. 18: 113.

4. Dent, P. B., and R. A. Good. 1965. Absence of antibody production in the Bursa of Fabricius. Nature (London). 207:491.

5. Waksman, B. H., B. G. Arnason, and B. D. Jankovic. 1962. Role of thymus in immune reactions in rats. III. Changes in the lymphoid organs of thymectomized rats. J. Exp. Med.116:187.

6. Parrott, D. M. V., M. A. B. de Sousa, and J. East. 1966. Thymus dependent areas in the lymphoid organs of neonatally thymectomized mice. J. Exp. Med. 123: 191.

7. Lance, E. M., and R. N. Taub. 1968. Segregation of lymphocyte populations through differential migration. Nature (London). 221:841.

8. Raidt, D. J., R. I. Mischell, and R. W. Dutton. 1968. Cellular events in the immune response. Analysis and in vitro response of mouse spleen cell populations separated by differential flotation in albumin gradients. J. Exp. Med. 128:681.

9. Plotz, P. H., and N. Talal. 1967. Fractionation of splenic antibody-forming cells on glass bead columns. J. Immunol.99:1236.

10. Dicke, K. A., J. I. M. Van Hooft, and D. W. Van Bekkum. 1968. The selective elimination of immunologically competent cells from bone marrow and lymphatic cell mixtures. Transplantation. 6:562.

11. Singhal, S. K., F. Daguillard, and M. Richter. 1968. Cells involved in the immune response. II. The response of normal rabbit haematopoietic and lymhopoietic cells to phytohemagglutinin in vitro. Int. Arch. Allergy Appl. Immunol. 34:119. 
12. Singhal, S. K., and M. Richter. 1968. Cells involved in the immune response. IV. The responses of normal and immune rabbit bone marrow and lymphoid tissue lymphocytes to antigens in vitro. J. Exp. Med. 128:1099.

13. Daguillard, F., and G. Edsall. 1968. The agglutinating and bacterial activity of IgM and IgG antibodies to the 9 and 12 factors of Salmonella typhi $O 901 . J$. Immunol. 100:1112.

14. Bach, F. H., and N. K. Voynow. 1966. One way stimulation in mixed leukocyte cultures. Science (Washington). 153:545.

15. Stelos, P. 1967. Isolation of immunoglobulin. In Handbook of Experimental Immunology. D. M. Weir, editor, Blackwell Scientific Publications Ltd. Oxford. 112.

16. McFarlane, A. S. 1958. Efficient trace-labelling of proteins with iodine. Nature (London). 182:53.

17. Moller, G. 1969. Induction of DNA synthesis in normal human lymphocyte cultures by antigen-antibody complexes. Clin. Exp. Immunol. 4:65.

18. Bloch-Shachter, N., K. Hirschhorn, and J. W. Uhr. 1968. The response of lymphocytes from non-immunized humans to antigen-antibody complexes Clin. Exp. Immunol. 3:889.

19. Naspitz, C. K., and M. Richter. 1968. The metabolism of phytohemagglutinin during incubation with human peripheral lymphocytes. Brit. J. Haematol. 16:77.

20. Knight, S., J. Bradley, J. J. Oppenheim, and N. R. Ling. 1968. The in vitro transformation of thymocytes and lymphocytes from humans, rabbits and guinea pigs and from thymomas. Clin. Exp. Immunol. 3:323.

21. Claman, H. N., and F. H.r Bunstetter. 1968. The response of cultured human thymus cells to phytohemagglutinin. $J$. Immunol. 100:1127.

22. Merler, E., and C. A. Janeway. 1968. Immunochemical identification of the cytophilic antibody in human lymphocytes. Proc. Nat. Acad. Sci. U.S.A. 59:393.

23. Paul, W. E., G. W. Siskind, and B. Benacerraf. 1967. Specificity of cellular immune responses. Antigen concentration dependence of stimulation of DNA synthesis in vitro by specifically sensitized cells, as an expression of the binding characteristics of cellular antibody. J. Exp. Med. 127:25.

24. McConnell, I., A. Munro, B. W. Gurner, and R. R. A. Coombs. 1969. Studies on actively allergized cells. $I$. The cytodynamics and morphology of rosette-forming lymph node cells in mice and inhibition of rosette-formation with antibody to mouse immunoglobulins. Int. Arch. Allergy Appl. Immunol. 35:209.

25. Mitchison, N. A. 1967 . Antigen recognition responsible for the induction in vitro of the secondary response. Cold Spring Harbor Symp. Quant. Biol. 32:431.

26. Singhal, S. K., and H. Wigzell. 1969. Antigen specific receptors on the outer surface of virgin immunocytes of the normal bone marrow. Fed. Proc. 28:309.

27. Richter, M., and N. I. Abdou. 1969. Cells involved in the immune response. VII. Antibody formation by radioresistant cells of irradiated rabbits injected with normal allogeneic bone marrow cells and sheep erythrocytes. J. Exp. Med., 129: 1261.

28. Sell, S., and P. G. H. Gell. 1965. Studies on rabbit lymphocytes in vitro. I. Stimulation of blast transformation with an antiallotype serum. J. Exp. Med.122:423.

29. Sell, S., D. S. Rowe, and P. G. H. Gell. 1965. Studies on rabbit lymphocytes in 
vitro. III. Protein, RNA, and DNA synthesis by lymphocyte cultures after stimulation with phytohemagglutinin, with staphylococcal filtrate, with antiallotype serum, and with heterologous antiserum to rabbit whole serum. $J$. Exp. Med. 122:823.

30. Sell, S. 1967. Studies on rabbit lymphocytes in vitro. VII. The induction of blast transformation with the $F(a b)^{2}$ and $F a b$ fragments of sheep antibody to rabbit IgG. J. Immunol. 98:786.

31. Foerster, J., J. P. Lamelin, I. Green, and B. Benacerraf. 1969. A quantitative study of the stimulation of DNA synthesis in lymph node cell cultures by antilymphocyte serum, anti-gamma globulin serum, specific antigen, and phytohemagglutinin. J. Exp. Med. 129:295.

32. Skamene, E., and J. Ivanyi. 1969. Lymphocyte transformation by $\mathbf{H}$-Chain specific anti-immunoglobulin sera. Nature (London). 221:681.

33. Skamene, E., J. Sejkorova, K. Nouza, and J. Ivanyi. 1968. Stimulation of DNA synthesis in the culture of mouse spleen cells by means of heterologous antilymphocyte and antiglobulin sera. Folia Biol. (Praha). 14:289.

34. Adinolfi, M., B. Gardner, F. Giannelli, and M. McGuire. 1967. Studies on human lymphocytes stimulated in vitro with anti-gamma and anti- $\bar{\mu}$ antibodies. $E x$ perientia (Basel). 23:1.

35. Oppenheim, J. J., G. N. Rogentine, and W. D. Terry. 1969. Transformation of human lymphocytes by monkey antisera to human immunoglobulins. Immunology. 16:123.

36. Daguillard, F., D. Heiner, M. Richter, and B. Rose. 1969. The response of leucocytes of agammaglobulinemia subjects to phytohemagglutinin and antiimmunoglobulin antiserum. Clin. Exp. Immunol. 4:203.

37. McKenzie, I. F. C., P. J. Morris, P. Schiff, G. De Gabriele, and S. K. Sutherland. 1969. Human antilymphocytic serum. I. Production and in-vitro testing. Med. J. Aust. 1:203.

38. Holt, L. J., N. R. Ling, and D. R. Stanworth. 1966. The effect of heterologous antisera and rheumatoid factor on the synthesis of DNA and protein by human peripheral lymphocytes. Immunochemistry. 3:359.

39. Grasbeck, R., C. T. Nordman, and A. De La Chapelle. 1964. The leucocytemitogenic effect of serum from rabbits immunized with human leucocytes. Acta. Med. Scand. Suppl. 412:39.

40. Woodruff, M. F. A., B. Reid, and K. James. 1967. Effect of antilymphocytic antibody and antibody fragments on human lymphocytes in vitro. Nature (London). 215:591.

41. Storey, J., S. J. Hughes, and S. Sell. 1969. Stimulation of blast transformation of rabbit lymphocytes in vitro by xenogeneic antilymphocyte sera. Fed. Proc. 28: 294.

42. Alm, G. V., and R. D. A. Peterson. 1969. The in vitro response of spleen cells from hypogammaglobulinemic bursectomized irradiated chickens to anti-immunoglobulin serum. Fed. Proc. 28:310.

43. Mosedal, B., K. J. Felstead, and J. A. C. Parke. 1968. Effect of antilymphocyte serum on the response of human and mouse lymphocytes to PHA. Nature (London). 218:983. 
44. Lundgren, G., L. Collste, and G. Moller. 1968. Cytotoxicity of human lymphocytes: Antagonism between inducing processes. Nature (London). 220: 289.

45. Naspitz, C. K., and M. Richter. 1968. The action of phytohemagglutinin in vivo and in vitro. A review. Progr. Allergy. 12:1.

46. Claman, N. H., E. A. Chaperon, and R. F. Triplett. 1966. Thymus-marrow cell combinations. Synergism in antibody production. Proc. Soc. Exp. Biol. Med. 122:1167.

47. Cheng, V., and J. J. Trentin. 1967. Origin and Function of hemolytic antibody forming cells of the spleen. Fed. Proc. 26:641.

48. Doria, G., and G. Agarossi. 1969. Immunologically competent thymus cells of bone marrow origin. Nature (London). 221:871.

49. Skopinska, E., and E. Skamene. 1968. Stimulation of DNA synthesis in mixed lymphocyte culture of chickens. Folia Biol. (Krakow). 14:296.

50. Bain, B., M. Vas, and L. Lowenstein. 1964. The development of large immature mononuclear cells in mixed leucocyte culture. Blood J. Bematol. 23:108.

51. Chapman, N. D., and R. W. Dutton. 1965. The stimulation of DNA synthesis in culture of rabbit lymph node and spleen cell suspensions by homologous cells. J. Exp. Med. 121:85.

52. Huemer, P. R., L. S. Keller, and K. D. Lee. 1968. Thymidine incorporation in mixed culture of spleen cells from mice of differing $\mathrm{H}-2$ types. Transplantation. 6:706.

53. Main, R. K., and L. J. Cole. 1966. Immunological interaction between allogeneic and xenogeneic rodent spleen cells in culture: Stimulation of DNA synthesis. Clin. Exp. Immunol. 1:415.

54. Ling, N. R. 1968. Lymphocyte Stimulation, North Holland Publishing Co., Amsterdam. 131.

55. Bain, B., and L. Lowenstein. 1964. The mixed leukocyte reaction. Science (Washington). 145:1315.

56. Wilson, D. B. 1967. Quantitative studies on the mixed lymphocyte interaction in rats. I. Conditions and parameters of response. J. Exp. Med. 126:625.

57. Wilson, D. B., W. K. Silvers, and P. C. Nowell. 1967. Quantitative studies on the mixed lymphocyte interaction in rats. II. Relationship of the proliferative response to the immunologic status of the donors. J. Exp. Med.126:655.

58. Cohen, M. W., G. J. Thorbecke, G. M. Hochwald, and E. B. Jacobson. 1963. Induction of graft-versus-host reaction in newborn mice by injection of newborn or adult homologous thymus cells. Proc. Soc. Exp. Biol. Med. 114:242.

59. Yunis, E. J., H. Hilgard, K. Sjodin, C. Martinez, and R. A. Good. 1964. Immunological reconstitution of thymectomized mice by injections of isolated thymocytes. Nature (London). 201:784.

60. Sosin, H., Hillgard, H., and C. Martinez. 1966. The immunologic competence of mouse thymus cells measured by the graft versus host spleen assay. J. Immunol. 96:189.

61. Stuttman, O., E. J. Yunis, P. O. Teague, and R. A. Good. 1968. Graft-versus-host reactions induced by transplantation of parental strain thymus in neonatally thymectomized $\mathbf{F}_{1}$ hybrid mice. Transplantation. 6:514. 
62. Stuttman, O., and R. A. Good. 1969. Absence of synergism between thymus and bone marrow in graft-versus-host reactions. Proc. Soc. Exp. Biol. Med. 130:848.

63. Dukor, P., and F. M. Dietrich. 1967. Impairment of phytohemagglutinin-induced blastic transformation in lymph nodes from thymectomized mice. Int. Arch. Allergy Appl. Immunol. 32:521.

64. Meuwissen, J. H., P. J. Van Alten, F. H. Bach, and R. A. Good. 1968. Influence of thymus and bursa on in vitro lymphocyte function. In Immunologic Deficiency Diseases in Man. D. Bergsma, editor, The National Foundation, New York. 253.

65. Greaves, M. F., I. M. Roitt, and M. E. Rose. 1968. Effect of bursectomy and thymectomy on the responses of chicken peripheral blood lymphocytes to phytohemagglutinin. Nature (London). 220:293. 